\title{
PARADIGMA SISTEM DESENTRALISASI PENDIDIKAN SECARA HOLISTIK
}

\author{
Syahril Chaniago*
}

\begin{abstract}
Planned implementation of regional autonomy has been started since enacted in 2001 which refers again to the latest two laws, namely: Law No. 32 of 2004 on Regional Government and the number 33 of 2004 on Fiscal BalanceRegional Center. Autonomy with the affairs of the Authority shall be to all services delivered indirectly to the district / city and province with the General Allocation Fund (DAU), whereas dealings with the option Special Allocation Fund (DAK). Centralized system changes pemedntahan be desentralisfik is a new paradigm that became the basis of systematic thinking, especially in terms of the national policy on education (Education).
\end{abstract}

Keywords: regional autonomy, regional government, education

\section{PENDAHULUAN}

Implementasi otonomi daerah yang direncanakan telah dimulai sejak diberiakukan pada tahun 2001 mengacu lagi pada dua UU. terbaru, yaitu: UU nomor 32 tahun 2004 tentang Pemerintahan Daerah dan nomor 33 tahun 2004 tentang Perimbangan Keuangan PusatDaerah. Otonomi dengan Kewenangan wajib untuk semua urusan pelayanannya diserahkan Iangsung kepada daerah kabupaten/kota dan propinsi

\footnotetext{
* Syahril Chaniago adalah Dosen Universitas Pakuan Bogor
}

dengan Dana Alokasi Umum (DAU), sedangkan urusan pilihan dengan Dana Alokasi Khusus (DAK). Perubahan sistem pemedntahan yang sentralistik menjadi desentralisfik merupakan paradigma baru yang menjadi dasar berfikir secara sistematis khususnya dalam hal kebijakan sistem pendidikan nasional (SISDIKNAS).

Sektor pendidikan merupakan salah satu sektor yang termasuk sektor pelayanan dasar yang akan mengalami perubahan secara mendasar dengan akan dilaksanakannya otonomi daerah dan desentralisasi fiskal, balk dad 
segi birokrasi kewenangan penyelenggaraan pendidikan maupun dad aspek pendanaannya. PP tentang Pemerintah Daerah dan Penmbangan Keuangan PusatDaerah secara resmi diberlakukan pemerintah, maka antisipasi implikasi otonomi daerah terhadap sektor pendidikan hanya dapat dilakukan dengan mengacu pada UU nomor 32 dan 33 tahun 2004. Tulisan singkat ini bertujuan untuk mengkaji implementasi UU Pemerintahan Daerah dan UU Penmbangan Keuangan Pusat-Daerah terhadap Desentralisasi Pendidikan dengan membahas: Pertama, prinsipprinsip sistem desentralisasi pendidikan yang hoistik serta bagaimana proses desentralisasi dapat mempengaruhi faktor-faktor yang akan menentukan efektifitas sekolah.

\section{TINJAUAN PUSTAKA}

Prinsip Berfikir Dalam Sistem Desentralisasi Pendidikan

Secara

konseptasi,

terdapat dua jenis desentralisasi pendidikan, yaitu: pertama, desentralisasi kewenangan di sektor pendidikan dalam hal kebijakan pendidikan dan aspek pendanaannya dari pemerintah pusat ke pemerintah daerah (propinsi dan distrik), dan kedua, desentralisasi pendidikan dengan fokus pada pemberian kewenangan yang Iebih besar di tingkat sekolah. Konsep desentralisasi pendidikan yang pertama terutama berkaitan dengan otonomi daerah dan desentralisasi penyelenggaraan pemerintahan dari pusat ke daerah, sedangkan konsep desentralisasi pendidikan yang memfokuskan pada pemberian kewenangan yang Iebih besar pada tingkat sekolah dilakukan dengan motivasi untuk meningkatkan kualitas pendidikan. Dengan demikian perlu perubahan pola fikir para pengelola pendidikan baik di tingkat pusat, daerah dan pada tingkat sekolah.

Tujuan dan orientasi dari desentralisasi pendidikan sangat bervariasi berdasarkan pengalaman desentralisasi pendidikan yang dilakukan di beberapa negara Amerika Latin, di Amerika Serikat dan Eropa yang lama memakai pendekatan sistem. Jika yang menjadi tujuan adalah pemberian kewenangan di sektor pendidikan yang lebih besar kepada pemerintah daerah, maka fokus desentralisasi pendidikan yang dilakukan adalah pada pelimpahan kewenangan yang lebih besar kepada pemerintah lokal atau kepada Dewan Sekolah. Implisit ke dalam strategi desentralisi pendidikan yang seperti ini adalah target untuk mencapai efisiensi 
dalam penggunaan sumber daya (school resources; dana pendidikan yang berasal yang pemerintah dan masyarakat). Akan tetapi yang menjadi persoalan akhir-akhir ini menunjukkan bahwa daerah masih belum mampu melaksanakan system desentralisasi pendidikan karena masih kekurangan kapasitas dan belum diikuti dengan perubahan dari semua lini baik sekolah, pemerintah dan masyarakat.

Dilain pihak, jika yang menjadi tujuan desentralisasi pendidikan adalah peningkatan kualitas proses belajar mengajar dan kualitas dan hasil proses belajar mengajar tersebut, maka desentralisasi pendidikan lebih difokuskan pada reformasi proses belajar mengajar yang terintegrasi secara menyeluruh. Partisipasi orang tua dalam proses belajar mengajar dianggap merupakan salah satu faktor yang paling menentukan.

Dalam kenyataannya, desentralisasi pendidikan yang dilakukan di banyak negara merupakan bagian dan proses reformasi sistem pendidikan secara keseluruhan dan tidak sekedar merupakan bagian dan proses otonomi daerah dan desentralisasi fiskal. Desentralisasi pendidikan akan meliputi suatu proses pemberian kewenangan yang lebih holistik di bidang kebijakan pendidikan dan aspek pendanaannya dan pemenntah pusat ke pemerintah lokal dan pads saat yang bersamaan kewenangan yang lebih besar juga dibenkan pada tingkat sekolah.

Tabel 1. Tipologi Kewenangan-kewenangan Pendidikan yang dapat Didesntralisasikan

\begin{tabular}{|c|c|}
\hline & Kewenangan dalam \\
\hline $\begin{array}{l}\text { Organisasi pada proses } \\
\text { belajar mengajar }\end{array}$ & $\begin{array}{l}\text { Menetukan sekolah mana yang dapat diikuti } \\
\text { seorang murid. } \\
\text { Waktu belajar disekolah. } \\
\text { Penentuan buku yang digunakan. } \\
\text { Kurikulum. } \\
\text { Metode pembelajaran. }\end{array}$ \\
\hline Manajemen guru & $\begin{array}{l}\text { Memilih dan memberhentikan kepala sekolah. } \\
\text { Memilih dan memberhentikan guru. } \\
\text { Menentukan gaji guru. } \\
\text { Memberikan tanggung jawab pengajaran kepada }\end{array}$ \\
\hline
\end{tabular}




\begin{tabular}{|l|l|}
\hline & Kewenangan dalam \\
\hline & $\begin{array}{l}\text { guru. } \\
\text { Menentukan dan mengadakan pelatihan kepada } \\
\text { guru. }\end{array}$ \\
\hline $\begin{array}{l}\text { Struktur dan } \\
\text { perencanaan }\end{array}$ & $\begin{array}{l}\text { Membuka atau menutup suatu sekolah. } \\
\text { Menentukan program yang ditawarkan disekolah. } \\
\text { Definisi dari isi mata pelajaran. } \\
\text { Pengawasan atas kinerja sekolah. }\end{array}$ \\
\hline Sumber daya & $\begin{array}{l}\text { Program pengembangan sekolah. } \\
\text { Alokasi anggaran untuk guru dan tenaga } \\
\text { administrative personal. } \\
\text { Alokasi anggaran non-personal. } \\
\text { Alokasi anggaran untuk pelatihan guru. }\end{array}$ \\
\hline
\end{tabular}

Dari pengalaman Negaranegara maju (OECD) dan beberapa negara Amerika latin yang telah melakukan sistem desentralisasi pendidikan dapat ditarik suatu benang merah yang memberikan kesimpulan sebagai berikut. Di negara-negara yang tergabung dalam OECD, kewenangankewenangan dalam hal: penentuan buku pelajaran, metode pembelajaran, tanggung jawab dalam pelaksanaan rencana pengembangan sekolah cenderung berlaku di tingkat sekolah dan tidak tergantung pada tingkat desentralisasi dalam penyelenggaraan pemerintahan. Sedangkan pengamatan di negaranegara Amerika Latin menyimpulkan bahwa kewenangan dalam menentukan kurikulum inti tetap berada pada pemerintah pusat, demikian pula dengan kewenangan dalam melaksanakan ujian-ujian yang diberiakukan secara nasional. Kesimpulan ini bedaku secara umum di negara-negara Amerika Latin, dan tidak tergantung pada tingkat desentralisasi dalam penyelenggaran pemerintahan dan masing-masing negara. Desentralisasi pendidikan yang terjadi di negara-negara Amerika Latin tersebut merupakan bagian dad desentralisasi politik dan fiskal penyelenggaraan pemerintahan, dari sistem pendidikan yang sentralistik ke sistem yang memberikan kewenangan lebih besar pada pemerintah daerah dan sistem yang melibatkan partisipasi masyarakat. Desentralisasi pendidikan diharapkan akan mampu meningkatkan kuantitas dan kualitas pendidikan, meskipun studi empiris 
tentang hal ini di negara-negara Amerika Latin belum dapat dilakukan karena keterbatasan data.

Salah satu cara dalam mempersiapkan desentralisasi pendidikan adalah dengan mengidentifikasi faktor-faktor yang mempengaruhi proses dan hasil belajar-mengajar, khususnya dad sekolah-sekolah unggulan.

Berdasarkan bahwa

(Mohrman and Wohltetter, 1994; Creemers, 1994 and DarlingHammond, 1997 seperti dikutip Burki, et.al., 1999) menyimpulkan bahwa sekolah ungguian memiliki karakteristik-karakteristik berfikir holistik dalam hal hakekat (ontologi) objek formal dan pendekatan ilmiah (epistemologi) yang jelas dan etika/moral (aksiologi) seperti kepemimpinan yang kuat, staf pengajar dengan kualifikasi dan komitmen tinggi, fokus pada proses pembelajaran, dan bertanggung jawab terhadap hasil yang dicapai (lihat Tabel 2).

Proses desentralisasi sektor pendidikan yang meliputi pemberian kewenangan yang Iebih besar ke pemerintah daerah dalam alokasi anggaran dan perencanaan pendidikan di daerah, serta pemberian kewenangan yang lebih besar pada sekolah dalam manajemen guru, pendanaan, pemilihan kepala sekolah manajemen proses belajarmengajar diharapkan akan meningkatkan kualitas pendidikan.

Tabel 2. Karakteristik sekolah yang efektif

\begin{tabular}{|l|l|}
\hline $\begin{array}{l}\text { Karakter sekolah yang } \\
\text { efektif }\end{array}$ & $\begin{array}{l}\text { Variable desentralisasi yang akan memperkuat } \\
\text { karakteristik sekolah yang efektif }\end{array}$ \\
\hline kepemimpinan & $\begin{array}{l}\text { Kepala sekolah dipilih oleh masyarakat dengan } \\
\text { menggunakan kriteria yang transparan: } \\
\text { Program pengembangan sekolah disusun pada } \\
\text { tingkat local. } \\
\text { Pengalian dana untuk melaksanakan program- } \\
\text { program sekolah }\end{array}$ \\
\hline $\begin{array}{l}\text { Guru dengan kualifikasi } \\
\text { dan komitmen tinggi }\end{array}$ & $\begin{array}{l}\text { Sekolah diberi kewenangan untuk mengubah } \\
\text { kurikulum dan proses pembelajaran. } \\
\text { Kepala sekolah diberi wewenang untuk } \\
\text { mengevaluasi guru } \\
\text { Sekolah diberi kewenangan dan prasarana dana } \\
\text { untuk menentukan sendiri program pelatihan bagi }\end{array}$ \\
\hline
\end{tabular}




\begin{tabular}{|l|l|l|}
\hline \multicolumn{2}{|l|}{} & guru-gurunya. \\
\hline $\begin{array}{l}\text { Focus pada proses } \\
\text { pembelajaran }\end{array}$ & $\begin{array}{l}\text { Program pengembangan dan peningkatan kualitas } \\
\text { sekolah menekankan pada aspek peningkatan } \\
\text { proses pembelajaran } \\
\text { Keterbukaan informasi mengenai proses } \\
\text { pembelajaran yang dilaksanakan sekolah }\end{array}$ \\
\hline $\begin{array}{l}\text { Bertanggung jawab } \\
\text { terhadap hasil yang } \\
\text { dicapai }\end{array}$ & $\begin{array}{l}\text { Kepala sekolah diangkat berdasarkan masa } \\
\text { jabatan. Perpanjangan masa jabatan tergantung } \\
\text { pada prestasi dalam memenuhi target } \\
\text { peningkatan proses pembelajaran sekolah. }\end{array}$ \\
\hline
\end{tabular}

Dari Sistem Birokratik Menuju Sistem Desentralisasi pendidikan Holistik

Sistem pendidikan yang berlaku sampal saat ini bersifat sangat sentralistis, yang dimulai dari pemberilakuan satu kurikulum secara nasional, sampai dengan peranan pusat yang sangat dominan dalam pengelolaan guru (sekolah negeri). Misalnya, Pusat sangat dominan dan menentukan dalam setiap keputusan tentang proses rekrutmen, pengangkatan, penempatan, pembinaan dan mutasi guru. Demikian pula dari aspek keuangan. Gaji guru sekolah negeri ditetapkan dan dibayarkan pemerintah, meskipun gaji guru SD pengelolaannya dilaksanakan oleh Propinsi, sedangkan gaji guru SLTP dan SLTA langsung oleh Pusat melalui KPKN.

Dari segi dana di luar gaji yang dialokasikan pemerintah ke masing-masing sekolah, diberikan dengan cara alokasi dana dari pusat ke daerah (kabupaten/kota) berdasarkan jumlah sekolah yang ada di daerah tersebut. Mekanisme alokasi dana dilakukan dengan perhitungan sejumlah dana yang sama untuk setiap sekolah berdasarkan jenjang pendidikan, tanpa memperhitungkan jumlah murid, lokasi ataupun tingkat kemakmuran ekonomi daerah tersebut. Cara seperti ini jelas mengandung banyak kelemahan, karena tidak memperhatikan sisi pemerataan (equity) dan pemberdayaan dalam pengalokasian dana ke masing-masing sekolah.

Dengan proses desentralisasi yang diimplementasikan pemerintah melalui UU nomor 32 tahun dan UU nomor 33 tahun 2004 tentang Pemerintahan Daerah dan 
Perimbangan Keuangan PusatDaerah, dapat ditangkap prinsipprinsip dan arah baru dalam pengelolaan sektor pendidikan dengan mengacu pada pembagian kewenangan antara pemerintah pusat, propinsi dan kabupaten/kota serta perimbangan keuangan pusat daerah yang garis besarnya sebagai berikut :

Kewenangan Pemerintah Pusat:

Melaksanakan kewenangankewenangan Pemerintah dalam bidang-bidang

Pertahanan/Keamanan, Politik Luar Negen, Peradilan, Fiskal/Moneter, Agama serta kewenangan bidang Pemenntahan Iainnya dcn/atau Kebijakan Strategis yang ditetapkan dengan Peraturan Pemerintah $^{3}$

Kewenangan Pemerintah Propinsi: Kewenangan bidang pemerintahan yang bersifat lintas kabupaten dan kota yang menjadi tanggung jawab Propinsi, misalnya adalah kewenangan di bidang pekerjaan umum, perhubungan, kehutanan, dan perkebunan disamping kewenangan bidang pemerintahan tertentu lainnya. ${ }^{4}$

Kewenangan Pemerintah Kabupaten/Kota: Mencakup semua kewenangan Pemerintahan selain kewenangan Pemerntah Pusat dan Propinsi. Secara eksplisit dinyatakan bahwa bidang pemerintahan yang wajib dilaksanakan daerah kabupaten dan daerah kota meliputi: pekerjaan umum, kesehatan, pendidikan, pertanian, perhubungan, perdagangan dan industri, penanaman modal, lingkungan hidup, dan pertanahan.

Disisi fiskal, perimbangan keuangan Pusat- Daerah menurut UU nomor 33 tahun 2004 (UUPKPD) mengetur pembagian keuangan antara Pemerintah Pusat dan Daerah, dengan mempertimbangkan aspek pemerataan antar daerah, potensi, kondisi, kebutuhan obyektif daerah serta tata cara pengelolaan dan pengawasan pelaksanaannya.

Sumber-sumber penerimaan daerah menurut UU-PKPD meliputi: (i). Pendapatan Asli Daerah (PAD); (ii). Dana Perimbangan; (iii). Pinjaman Daerah; (iv). Lain-lain pendapatan yang sah. Daerah melaksanakan semua kewenangannya yang berkaitan dengan desentralisasi dengan dibiayai dan anggaran daerah.

Penerimaan daerah yang berupa PAD masih mengacu pada UU nomor 18 tahun 1997 tentang pajak daerah dan retribusi daerah. Dana Perimbangan terdiri dari bagian 
daerah atas hasil Sumber Daya Alam, Pajak Bumi dan Bangunan, Bea Perolehan Hak atas Tanah dan Bangunan; Dana Alokasi Umum dan Dana Alokasi Khusus. Dana Alokasi Umum merupakan transfer dari pusat ke daerah dalam bentuk block grant, dengan kriteria alokasi berdasarkan potensi ekonomi daerah dan kebutuhan obyektif daerah. Penggunaan Dana Alokasi Umum diserahkan sepenuhnya pada daerah Dana Alokasi Khusus merupakan transfer dan pusat ke daerah yang bersifat spesifik, yang peruntukannya ditetapkan.

Implikasi otonomi daerah bagi desentralisasi pendidikan sangat tergantung pada pembagian kewenangan di bidang pendidikan yang akan ditangani pemerintah pusat, pemerintah propinsi dan pemerintah kabupaten/kota. Jika mengacu pada UU nomor 32 tahun 2004, maka kewenangan di sektor pendidikan yang terkait dengan (i) perencanaan nasional dan pengendalian pembangunan sektoral dan nasional secara makro; (ii) kebijakan pembinaan dan pemberdayaan sumber daya manusia; (iii) kebijakan standarisasi nasional akan ditangani pusat, Iainnya akan ditangani daerah, khususnya daerah kabupaten/kota. Namun sekarang urusan pendidikan merinci hasil hasil pembahasan sebagai berikut:
Kewenangan Pemerintah Pusat:

Kebijakan

nasional, standar/norma pendidikan, pendidikan karakter bangsa, pengendalian dan jaminan mutu pendidikan (educational quality control), dan pendidikan tinggi.

Kewenangan Pemerintah Propinsi:

Pendidikan luar biasa, LPTK, pendidikan lintas kabupaten, koordinasi, guru dan tenaga pendidik lainnya.

Kewenangan

Pemerintah

KabuDaten/Kota:

Pendidikan dasar, pendidikan menengah koordinasi ngan propinsi, PAUD, PNF kepemudaan, keolahragaan, :statjstik pen idikan, pendidikan masyarakat pertanahan.

Masih belum jelas benar interpretasi pelaksanaan desentralisasi di bidang Pendidikan dengan mengacu UU nomor 33 tahun 2004 karena belum ada Standar yang jelas. Bagaimana dengan status kepegawaian guru, apakah tetap sebagai PNS nasional atau menjadi PNS daerah?. Status guru sebagai PNS pusat atau daerah akan sangat berpengaruh pada alokasi anggaran, pembiayaan melalui APBN atau APBD. Implikasi lain dari status guru adalah fleksibilitas daerah dan sekolah 
dalam proses rekrutmen, pengangkatan, penempatan, mutasi, pemberhentian guru, serta evaluasi atas kinerja guru. Tapi sekarang kecendrungannya kembali menjadi kewenangan pusat.

art aspek kurikulum, perlu kejelasan tentang kebijakan perumusan kurikulum, apakah hanya kurikulum inti yang akan ditetapkan oleh pemerintah pusat, sedangkan muatan lokal dalam persentase yang cukup signifikan diserahkan pada masing-masing daerah atau bahkan langsung pada masingmasing sekolah. Saat ini kurikulum sepenuhnya ditentukan oleh Pemerintah Pusat (Kurikulum Berbasis Kompetensi), dan daerah hanya dapat mengisi bagian kurikulum yang berupa muatan lokal dalam persentase yang sangat kecil. Misalnya: di Jambi , muatan lokal kunkulum ditetapkan mata pelajaran bahasa Melayu dan TNKS.

Mengenai alokasi dana dari pusat ke daerah, sampai saat ini telah ada kejelasan tentang perumusan alokasi DAU dan DAK ke daerah, apakah dana yang ditransfer pusat sebagai DAU sudah mencakup alokasi anggaran rutin dan pembangunan untuk sektor pendidikan? Ataukah dana yang termasuk dalam transfer DAU hanya diperuntukan bagi pembiayaan pengeluaran-pengeluaran non- personnel dart sektor pendidikan, karena Guru masih akan berstatus sebagai PNS Pusat? Hal-hal seperti ini akan sangat tergantung pada keputusan untuk tetap mempertahankan status guru sebagai PNS Pusat atau mendesebtralisasikan

pengelolaan guru kepada daerah sepenuhnya. Demikian pula dengan alokasi daerah DAK ke daerah, sektor prioritas apa saja yang masih diberikan DAK kedaerah, pengalokasiannya dan apakah sector pendidikan termasuk sector yang akan diberikan DAK, misalnya untuk daerah-daerah dengan pencapaian standar tingkat pendidikan dibawah rata-rata nasional. Jika dana pendidikan untuk rutin (gaji guru) dan non-Min ditransfer sepenuhnya ke daerah melalui mekanisme DAU, maka berapa besar yang akan dialokasikan ke sektor pendidikan akan tergantung pada prioritas masing-masing daerah. Prioritas alokasi dana daerah selanjutnya tergantung pada pemerintah daerah dan DPRD setempat. Mengingat sektor pendidikan merupakan salah satu sektor pelayanan dasar, masih periu adanya suatu ketentuan standar minimal pendidikan yang harus dicapai daerah, sehingga daerah memiliki acuan yang harus dicapai dalam perencanaan sektor pendidikan. 


\begin{abstract}
Pertanyaan terpenting tentang arah desentralisasi pendidikan adalah sampai seberapa jauh sekolah-sekolah akan diberi kewenangan yang lebih besar menentukan kebijakankebijakan: organisasi dan proses belajarmengajar, manajemen guru, struktur dan perencanaan di tingkat sekolah, dan sumbersumber pendanaan sekolah.

Desentralisasi pendidikan yang efektif tidak hanya melibatkan proses pemberian kewenangan dan pendanaan yang lebih besar dan pusat ke daerah, tetapi juga meliputi pemberian kewenangan yang Iebih besar ke sekolah-sekolah, sehingga mereka dapat merencanakan proses belajar-mengajar dan pengembangan sekolah sesuai dengan kondisi dan kebutuhan masing-masing sekolah.
\end{abstract}

\section{PENUTUP}

Pelaksanaan otonomi daerah dan perimbangan keuangan pusatdaerah telah diimplementasikan pada tahun 2001 merupakan momentum yang sangat tepat untuk merefomiasi dan melakukan perubahan secara holistik dalam penyelenggaraan pendidikan dari aspek birokrasi, pendanaan, dan manajemen pendidikan.

Desentralisasi pendidikan yang efektif tidak hanya melibatkan proses pemberian kewenangan dan pendanaan yang Iebih besar dad pemerintah pusat ke pemerintah daerah, tetapi desentralisasi juga harus menyentuh pola berfikir secara sistematis kewenangan yang Iebih besar ke sekolahsekolah dalam menentukan kebijakan-kebijakan: organisasi dan proses belajar-mengajar, manajemen guru, struktur dan perencanaan di tingkat sekolah, dan sumbersumber pendanaan sekolah.

\section{DAFTAR PUSTAKA}

1998, "desentralisasi Kebijakan dan Tuntutan Perimbangan Keuangan Daeah" Orasi Ilmiah pada Dies ke 41 Ekonomi Universitas Padjadjaran, Bandung 24 Oktober.

Bray, Mark, 1996, Decentralization of Education: Community Financing, The World Bank: Directions in Development, Washington, D.C.

Burki, Shahid J., Guillermo E. Pent' and William R. Dillinger, 1999, Beyond the Center.' Decentralizing the State, The World Bank, Washington, D.C.

Chourmain Imam (2003). System Thingking: Model Berfikir Holistics. Program Pascasarjana Universitas 
Neged Jakarta.

David Osborne dan Ted Gaebler, 1992, "Reinventing Govemment": How the Entrepreneurial Spirit is Transforming the public Sector. Terjemahan PPM, Jakarta.

Patrinos, Harry A. and David L. Ariasingam,1997, Decentralization of Education.Demand-Side Financing, The World Bank: Directions in Development, Washington, D.C.

Republik Indonesia, 1999, UU nomor 22 tentang Pemerintahan Daerah, Mei. 1999, UU nomor 25 tentang Perimbangan Keuangan antara Pemerintah Pusat dan Daerah, Mei.

Shah, Anwar, 1998, "Balance, Accountability, and Responsiveness: Lessons about Decentralization', dalam Picciotto, Robert and Eduardo Wiesner (eds.),

Evaluation and Development: The Institutional Dimension, New Brunswick, USA and London, UK: Transaction Publishers. 